\title{
Marina Point, Ltd. v. Wolfson: Discrimination in Rental Housing Against Families With Cliildren
}

In Marina Point, Ltd. v. Wolfson, ${ }^{1}$ the California Supreme Court held that a landlord's policy of refusing to lease apartments to families with children violated the Unruh Civil Rights Act's prohibition against arbitrary discrimination in the provision of private services and facilities. $^{2}$ The court found that the Unruh Act regulates proprietors in the busmess of leasing housing accommodations; protects all persons, including families with children, against arbitrary discrimination; and confers upon all persons an individual right to such protection. These findings enabled the court to conclude that because the "no children" policy at Marina Point excluded tenants based on generalized predictions of misconduct by children as a class, the policy constituted arbitrary discrimination prohibited by the Unruh Act.

This Note argues that the court wrongly concluded that "no children" policies violate the Unruh Act. Part I presents the facts of the case, the opinions of the justices, and the relevant legal background. Part II agrees with the court that the Unruh Act prohibits arbitrary discrimination by landlords, and that families with children are "persons" within the Unruh Act, but argues that the Legislature did not intend "no children" policies to be treated as arbitrary discrimination under the statute. Part II also assesses the conflicting interests at stake in Marina Point and concludes that "no children" pohcies are reasonable, and thus should not be prohibited under the statute. Part III explores the difficulties of enforcing the court's decision and proposes an alternativc solution to the problem of housing shortages for families with children. The proposal delegates to local governments the responsibility for addressing the problem, thus affording each government flexibility in selecting a remedy that best suits its community.

1. 30 Cal. 3d 721, 640 P.2d 115, 180 Cal. Rptr. 496, cert. denied, 103 S. Ct. 129 (1982).

2. This section shall be known, and may be cited, as the Unruh Civil Rights Act. All persons within the jurisdiction of this state are free and equal, and no matter what their sex, race, color, religion, ancestry, or national origin are entitled to the full and equal accommodations, advantages, facilities, privileges, or services in all busimess establishments of every kind whatsoever.

This section shall not be construed to confer any right or privilege on a persou which is conditioned or limited by law or which is applicable alike to persons of every sex, color, race, religiou, ancestry, or national origin.

CAL. CIV. Code \& 51 (West 1982). 
The CASE

\section{A. The Facts}

In February 1974, Stephen and Lois Wolfson moved imto Marina Point, Ltd., an 846-unit apartment complex in Marina Del Rey, California. Eight months later, with the objective of eventually excluding all children from the complex, the owner of the complex introduced a policy against granting new leases to families with children. ${ }^{3}$ In September 1975, Mrs. Wolfson gave birth to her first child; however, neither she nor her husband notified the landlord of the birth. In the fall of 1976, when the landlord learned of the child, he inforined the Wolfsons that their lease would not be renewed, solely because of the child's presence. When the Wolfsons failed to vacate the apartment after their lease expired, the landlord filed an unlawful detamer action.

The Wolfsons defended on the grounds that the exclusionary policy violated both constitutional and statutory proscriptions against discrimination, imcludimg proscriptions contamed in the Unruh Civil Rights Act. ${ }^{4}$ At trial, the landlord demed that his policy violated any such principles. The landlord mtroduced evidence of dangerous and annoying behavior previously engaged im by children at the apartment complex, ${ }^{5}$ and of the unsuitability of the complex for children. ${ }^{6}$ In addition, he presented expert testimony that children are generally more destructive of property than are adults, resultimg in higher maintenance costs to landlords who rent to families with children. The Wolfsons presented testimony by neighbors that the child's presence was not disturbing, and presented expert testimony that the cost of operating an apartment complex does not vary with the age of its tenants. The Wolfsons also introduced studies documenting the magnitude of the

3. More than sixty families with children lived in the complex when the policy was instituted. 30 Cal. 3d at 726, 640 P.2d at 117-18, 180 Cal. Rptr. at 499.

4. The Wolfsons alleged violations of the Unruh Civil Rights Act, CAL. CIv. CODE $\$ 51$ (West 1982), the Fair Housing Law, CAL. HeALTH \& SAFETY CODE $\$ \S 35700-35745$ (repealed 1980 ), and of their rights to familial privacy and equal protection of the law as guaranteed by the state and federal constitutions. Marina Point, 30 Cal. 3d at 730, 640 P.2d at 120, 180 Cal Rptr. at 502.

5. Young tenants had allegedly committed acts of arson and engaged in sucl activities as batting practice and roller skating in the liallways. However, the landlord presented no evidence to show: (1) the proportion of child tenants engaging in sucl activities; (2) whiat steps short of a moratoriun on all new leases to families with children liad been taken to alleviate the problem; or (3) that the Wolfson's child had engaged in any annoying behavior. Id. at 727-28, 640 P.2d at 118, 180 Cal. Rptr. at 500.

6. The apartment manager testified that the Marina Point complex was not designed for habitation by children. The complex lacked playground areas and equipment, and neither of its swimming pools had a slrallow end. In addition, there were ungated gangplanks leading to the ocean. Id. at 728,744 n.13, 640 P.2d at 118, 129 n.13, 180 Cal. Rptr. at 500, 510 n.13. 
problem of discrimination against families with children in California's rental housing market. ${ }^{7}$

The mumicipal court ruled in favor of Marina Point, holding that the absence of any specific statutory provision or judicial decision prohibiting discrimination against families with children placed the landlord's exclusionary practice outside the reach of California's existing antidiscrimination law. ${ }^{8}$ The court made findings of fact that the Marina Point facilities were designed for adult use and posed dangers to children unaccompanied by adults. The court also found that the landlord's pohicy was rationally related to the lack of facilities provided for children. ${ }^{9}$ Finally, the court found the exclusionary pohicy proceeded from a reasonable economic motive to provide a quiet and peaceful atmosphere. ${ }^{10}$ The court of appeal affirmed. ${ }^{11}$

\section{B. The Opinions}

The California Supreme Court reversed. In a majority opimion written by Justice Tobriner, the court held that the broad, class-based pohicy of excluding children from rental housing violated the Unruh Act. ${ }^{12}$ The court first decided that the antidiscrimination provisions of the Unruh Act are not confined in their apphication to a limitcd set of protected classes, but instead protect all persons, including families with children, from any arbitrary discrimination by the proprietor of a business estabhshment. ${ }^{13}$ To support this finding, the court relied on In re Cox,${ }^{14}$ a 1970 decision which held that the Unruh Act's hist of protected classes-color, race, religion, ancestry, and national origin-is illustrative rather than restrictive, and that the language and the history of the Act compel the conclusion that the Legislature intended to prohibit all arbitrary discrimination by busmess establislıments, regardless

7. Id. at 729 \& n.1, 640 P.2d at 119 \& n.1, 180 Cal. Rptr. at $501 \& \mathrm{n} .1$.

8. Marina Point, Ltd. v. Wolfson, No. A 15829, slip op. at 2 (Culver Mun. Ct. Oct. 21, 1977) (on file with the California Law Review). The court further lield that the constitutional rights of the Wolfsons liad not been violated. Id. at 3-4.

9. $30 \mathrm{Cal}$. 3d at 746-47, 640 P.2d at 130, $180 \mathrm{Cal}$. Rptr. at 512 (Ricliardson, J., dissenting); see also supra note 6.

10. $30 \mathrm{Cal} .3 \mathrm{~d}$ at $729,640 \mathrm{P} .2 \mathrm{~d}$ at $119,180 \mathrm{Cal}$. Rptr. at 501.

11. 97 Cal. App. 3d 278, 158 Cal. Rptr. 669 (1979), officially depublished pursuant to CAL. CT. R. 976(d). The court of appeal relied on Flowers v. John Burnhain \& Co., 21 Cal. App. 3d 700, 98 Cal. Rptr. 644 (1971) where the court had held that a landlord's policy of excluding families with male children over the age of five did not violate the Unruh Act. The court also rehied on the the legislature's failure to pass a number of bills designed to eliminate discrimination in rental housing against families with children. See infra notes 41-44.

12. Concurring in the opinion were Chief Justice Bird, Associate Justices Newinan and Broussard, and Court of Appeal Justice White (sitting by designation). The court did not reach the constitutional questions presented; they are not discussed in this Note.

13. $30 \mathrm{Cal}$. 3d at 730, 640 P.2d at 120,180 Cal. Rptr. at 502.

14. 3 Cal. 3d 205, 474 P.2d 992, 90 Cal. Rptr. 24 (1970). 
of the criteria upon which it is based. ${ }^{15}$ The court decided that the Legislature had incorporated the Cox interpretation when the Unruh Act was annended in 1974. ${ }^{16}$ The court dismissed as unpersuasive the fact that nine bills designed to curtail age discrimination in housing had been introduced in the Legislature since the 1974 ainendinent, yet had never been passed. ${ }^{17}$

Second, the majority held that the landlord's practice was arbitrary because it excluded persons on the basis of inembership in a class that the landlord believed was more likely to engage in misconduct than some other group. ${ }^{18}$ Relying on Cox and its predecessors, the court ruled that the right of access to business establishments is individual in nature, and that each class nember has the right to an evaluation based on his own behavior. ${ }^{19}$ While the court recognized the right of proprietors to protect their businesses from dainaging or disruptive conduct through deportinent regulations rationally related to the services and facilities provided, ${ }^{20}$ it held that they inay not pursue broad exclusionary pohicies based on class membership. ${ }^{21}$

The court rejected the trial court's finding that, based on the nature of Marina Point's facilities, the "no children" policy was reasonable rather than arbitrary. ${ }^{22}$ Children were previously permitted at the complex, the court noted, and "nothing in the nature of an ordinary apartment coinplex is incompatible with the presence of families with children." 23 The court distinguished the exclusionary policies of housing complexes reserved for older persons, stating that such policies were justified by public policy considerations. ${ }^{24}$

Justices Richardson and Mosk dissented. While agreeing with the majority that Marina Point was a business establishment and thus subject to the Unruh Act's proscription of arbitrary discrimination, they

15. Id. at 216,474 P.2d at 999,90 Cal. Rptr. at 31 .

16. It is a well-established principle of statutory construction that when the Legislature amends a statute without altering portions of the provision that have previously been judicially construed, the Legislature is presumed to have been aware of and to have acquiesced in the previous judicial construction. Accordingly, reenacted portions of the statute are given the same construction they received before the amendment.

30 Cal. 3d at 734, 640 P.2d at 123, 180 Cal. Rptr. at 504. The court also looked to legislative documents indicating that the legislature was aware of Cox's construction of the Unruh Act at the time the Act was amended. Id. at 735, 640 P.2d at 123, 180 Cal. Rptr. at 505.

17. $30 \mathrm{Cal} .3 \mathrm{~d}$ at 735 n.7, 640 P.2d at 123 n.7, 180 Cal. Rptr. at 505 n.7. See infra notes $41-44$ and accompanying text.

18. 30 Cal. $3 d$ at 739,640 P.2d at 125,180 Cal. Rptr. at 507.

19. Id. at $738-39,640$ P.2d at $125-26,180$ Cal. Rptr. at 507.

20. Id. at 737,640 P.2d at 124, 180 Cal. Rptr. at 506 (quoting Cox, 3 Cal. 3d at 217, 474 P.2d at 999,90 Cal. Rptr. at 31 ).

21. Id. at 740,640 P.2d at $126-27,180$ Cal. Rptr. at 508.

22. See supra note 6.

23. 30 Cal. $3 d$ at 741,640 P.2d at 127,180 Cal. Rptr. at 509.

24. Id. at 742-43, 640 P.2d at 127-28, 180 Cal. Rptr. at 509-10. 
nonetheless insisted that Marina Point had not violated the Act. The two justices noted that $C o x$ did not forbid the implementation of "reasonable regulations that are rationally related to the services performed and facilities provided."2s They argued that the landlord's rule was a "reasonable regulation" given the trial court's conclusion that Marina Poimt's exclusion of children was rationally related to the lack of facilities provided for thein. ${ }^{26}$ Because that conclusion was supported by express findings of fact and substantial evidence in the record, the two justices concluded that the court should have affirmed the trial court's judgment. ${ }^{27}$

\section{Legal Background}

\section{The Unruh Act}

Enacted in 1897, the public accommodations statute, as the predecessor of the Unruh Act was known, codified the common law doctrime that banned all discrimination by proprietors of public accommodations in the provision of services. ${ }^{28}$ In its early form, the statute applied only to certain businesses especially oriented to serving the public. ${ }^{29}$ In 1959 , the Legislature significantly altered the statute, and titled it the Unruh Civil Rights Act. The Legislature substituted "business establishments of every kind whatsoever" for the list of places of "public accommodation or amusement." The Legislature also listed five prohibited bases of discrimination: race, color, religion, ancestry, and na-

25. Id at 746, 640 P.2d at 130, 180 Cal. Rptr. at 512 (Richardson, J., dissenting) (cmphasis omitted) (quoting In re Cox, 3 Cal. 3d 205, 212, 474 P.2d 992, 995-96, 90 Cal. Rptr. 24, 27-28 (1970)).

26. $30 \mathrm{Cal}$. 3d at $746-47,640$ P.2d at 130-31, 180 Cal. Rptr. at 512 (Richardson, J., dissenting).

27. Id at 746-49, 640 P.2d at 130-32, 180 Cal. Rptr. at 512-13 (Richardson, J., dissenting). The dissenting justices further objected to the inajority's reliance on the fact that the previous landlord had allowed children at Marina Point. They argued that the previous landlord's practice should not bind subsequent landlords who wish to limit occupancy to conforn with the design and intended use of the facilities. Id. at 747,640 P.2d at 131, 180 Cal. Rptr. at 512-13 (Richardson, J., dissenting).

28. See generally Horowitz, The 1959 California Equal Rights in "Business Establishments" Statute—a Problem in Statulory Application, 33 S. CAL. L. Rev. 260, 276 (1960).

29. The 1897 version read as follows:

[A]ll citizens within the jurisdiction of this State shall be entitled to the full and equal accommodations, advantages, facilities, and privileges of inns, restaurants, liotels, eatinghouses, barber-shops, bath-liouses, theaters, skating-rinks, and all other places of public accommodation or amuseinent subject only to the conditions and limitations established by law and applicable alike to all citizens.

Act of Mar. 13, 1897, ch. 108, \& 1, 1897 Cal. Stat. 137, 137. Substantially identical language was codified in 1905, Act of Mar. 21, 1905, ch. 413, \& 1, 1905 Cal. Stat. 553, 553 (codified as amended at CAL. CIv. Code $\$ 51$ (West 1982)), amended in 1919, Act of May 5, 1919, ch. 210, § 1, 1919 Cal. Stat. 309, 309 (adding "public conveyances" after "skating rinks"), and again in 1923, Act of May 28,1923 , ch. $235, \S 1,1923$ Cal. Stat. 485, 485 (adding "places where ice cream or soft drinks of any kind are sold for consuinption on the premises" after "eating houses"). 
tional origin. The current text is virtually identical to the 1959 statute. $^{30}$

Subsequent judicial interpretations and legislative efforts focused on further defining both the business proprietors subject to the Act's proscriptions, ${ }^{31}$ and the prohibited bases of discrimination. For some years, the expansion of the bases of prohibited discrimination proceeded on a piecemeal basis. In Orloff v. Los Angeles Turf Club, ${ }^{32}$ the court held that the Unruh Act prohibited the exclusion of a inan from a racetrack solely because he was reputed to be of "immoral character." Soon after, in Stoumen $v$. Reilly, ${ }^{33}$ the protection afforded by the Unruh Act was extended to a homosexual man who had been refused service in a restaurant because of his sexual orientation. Finally, in In re Cox, ${ }^{34}$ the court abandoned the piecemeal approach. There, the plaintiff alleged he had been unlawfully excluded from a shopping center because his inale coinpanion had long hair and was unconventionally dressed. The California Supreme Court ruled that the Unruh Act protected the plaintiff from such arbitrary discrimination; however, its holding was not limited to the facts presented. Rather, the court held that both the history and the language of the statute displayed an intent to prohibit all arbitrary discrimination by business enterprises, whatever the basis. ${ }^{35}$

In 1974, the California Legislature amended the Unruh Act to add "sex" to the statute's list of illegal bases of discrimination. ${ }^{36}$ The amendment, oddly enough, postdated Cox's determination that the listing of prohibited bases of discrimination was illustrative only, and that the Unruh Act prohibited all arbitrary discrimination by business establishments. The legislative history of the amendment conclusively

30. See infra note 36. Two minor amendments were made after 1959. In 1961, "persons" was substituted for "citizens." Act of July 7, 1961, ch. 1187, § 1, 1961 Cal. Stat. 2920, 2920. In 1974, "sex" was added to the enumerated bases of prohibited discrimination. See infra notes 3637 and accompanying text.

31. Marina Point's holding that the busmess of renting housing accommodations is a "business establishment" subject to the proscriptions of the Unruh Act was clearly in accord with previous authority, and will not be discussed further in this Note. See Mulkey v. Reitman, 64 Cal. 2d 529, 413 P.2d 825, 50 Cal. Rptr. 881 (1966), affd, 387 U.S. 369 (1967) (implying a cause of action under the Unruh Act where plaintiffs alleged racial discrimination by apartment managers); Flowers v. John Burnham \& Co., 21 Cal. App. 3d 700, 98 Cal. Rptr. 644 (1971) (apartment complex was a "business establishment" under the Unrub Act).

32. 36 Cal. 2d 734, 227 P.2d 449 (1951).

33. 37 Cal. 2d 713, 234 P.2d 969 (1951).

34. 3 Cal. 3d 205, 474 P.2d 992, 90 Cal. Rptr. 24 (1970).

35. Id. at 216, 474 P.2d 999, 90 Cal. Rptr. 31.

36. Act of Sept. 23, 1974, ch. 1193, § 1, 1974 Cal. Stat. 2568, 2568. The statute's language was otherwise left intact. For the current version of the statute, see supra note 2. In Marina Point, the court found the last paragraph of the statute "confusing, and virtually incoherent," and refused to interpret it as contradicting its coustruction of the preceding paragraph. $30 \mathrm{Cal} .3 \mathrm{~d}$ at 734 , 640 P.2d at 123, 180 Cal. Rptr. at 504. 
estabhishes that the addition was not intended to alter the existing scope of the Act; rather, it was made only to highlight the fact that the Unruh Act provides a rennedy for sex discrimination. ${ }^{37}$ In light of this evidence of legislative intent, the Legislature, by leaving the rest of the statute intact at the time of the amendinent, may be deemed to have acquiesced in the court's holding in Cox that all arbitrary discrimination is forbidden. ${ }^{38}$

\section{Discrimination in Rental Housing Against Families With Children}

In 1971 a California lower court considered a question similar to that which would later arise in Marina Point. In Flowers v. John Burnham \& Co.,$^{39}$ the appellate court held that while an apartment complex was a business estabhishment under the ternus of the Unruh Act, its regulation excludimg male children over the age of five was not arbitrary, and therefore did not violate the statute. ${ }^{40}$ Flowers remained good law for eleven years-until Marina Point.

A movement began in the Legislature in 1975 to extend the protections of the Unruh Act and Cahfornia's Fair Housing Law to protect families with children against discrimination in rental housing. Between 1975 and 1981, nine bills were introduced in the Cahfornia Legislature that, had they passed, would have inade illegal inost such discrimination. The nine bills can be divided into three groups on the basis of certain shared characteristics. The first group consists of two

37. See infra text accompanying note 67 .

38. "It is a generally accepted principle that in adopting legislation the Legislature is presumed to have had knowlcdge of existing domestic judicial decisions and to have enacted and amended statutes in hight of such decisions as having a direct bearing upon them." Buckley v. Chadwick, 45 Cal. 2d 183, 200, 288 P.2d 12, 22 (1955) (citation omitted), quoted in Estate of McDill, 14 Cal. 3d 831, 839, 537 P.2d 874, 878, 122 Cal. Rptr. 754, 758 (1975). See also Brailsford v. Blue, 57 Cal. 2d 335, 339, 369 P.2d 13, 15, 19 Cal. Rptr. 485, 487 (1962) ("Parts of an amended statute not affected by the amendment will be given the same construction that they received before the amendment.").

39. 21 Cal. App. 3d 700, 98 Cal. Rptr. 644 (1971). See infra note 66.

40. Id. at 703, $98 \mathrm{Cal}$. Rptr. at 645 .

The California Attorney General has offered several opimions on the subject of discrimination against children under the Unruh Act. See 58 Op. Cal. Att'y Gen. 608, 613 (1975) (Whether discrimination in sale or rental of real property based on marital status or number of children is unlawful under the Unruh Act depends on whether the discrimination is found arbitrary, as determined by facts and circumstances.); 61 Op. Cal. Att'y Gen. 320, 322-23 (1978) (A regulation tlat prohibited unaccompanied children under fifteen from theatre prennises on Friday and Saturday evenings was found to be necessary to unaintain sufficient quiet and therefore a reasonable use restriction under the Unruh Act.); 59 Op. Cal. Att'y Gen. 70, 72 (1976) (Busimess restrictions prohibiting students froun frequenting commercial premises, limiting student patronage to a maximum number of students at one time, and levying minimuin charges on student purchases was found to be arbitrary under, the Unruh Act.).

While these opimions of the Attorney General are not controlling, they nonetheless merit the respect of the courts. Wenke v. Hitchcock, 6 Cal. 3d 746, 751-52, 493 P.2d 1154, 1158, 100 Cal. Rptr. 290, 294 (1972). 
bills that would have outlawed the termination of a lease because of the tenant's age or the presence of children in the tenant's household, unless the facilities were unsafe for the tenants. ${ }^{41}$ The second group consists of three bills that sought to prohibit all age discrimination in the leasing of nost housing accommodations. ${ }^{42}$ The third group consists of four bills specifically aimed at eliminating discrimination in the leasing of rental housing on the basis of the presence of minor children in the tenant's household. ${ }^{43}$ This third group represents the Legislature's attempts to enact what Marina Point later declared was already the law. Each of these nine bills failed to becoine law. ${ }^{44}$

41. Assembly Bill 2979, Cal. A. 2979, 1977-78 Reg. Sess. (1978), would have added a new section to the Health and Safety Code provisions relating to housing. Assenbly Bill 3000, Cal. A. 3000 , 1977-78 Reg. Sess. (1978), would have added a new chapter to Division 24 of the Health and Safety Code ("Community Development and Housing") that was repealed in 1980.

42. Senate Bill 1688, Cal. S. 1688, 1977-78 Reg. Sess. (1978), was proposed as an addition to Division 24 ("Community Development and Housing") of the Health and Safety Code. The bill would have prohibited apartment owners from relying on age in refusing to lease a unit or in discriminating in the terms, conditions, privileges, services, or facilities provided. Accommodations designed for occupation by the elderly, mobile home parks, and student dormitories were excepted. Two later bills also proposed to outlaw age discrimination in general. While the text of Senate Bill 2024, Cal. S. 2024, 1979-80 Reg. Sess. (1980), was very similar to Senate Bill 1688 of the prior year, Assembly Bill 3409, Cal. A. 3409, 1979-80 Reg. Sess. (1980), was substantially more detailed and coutained broader exceptions. Both bills would have added new sections to the Health and Safety Code. Assembly Bill 3409 would have prohibited discrimination against a lessee because of the age of the lessee or another person who would live on the premises. Discrimination was defined to include: (1) refusal to lease; (2) differentiation in terms, conditions, privileges, services, or facilities; (3) advertisement of intent to discriminate; or (4) false representations regarding availability. Exceptions ineluded premises unsafe for persons of a particular age, accommodations providing significant facilities or services primarily designed for a particular age group, premises governed by a consistent pohcy to maintain an environment compatible with a particular maturity, those providing distinctive furnishings such that occupancy by persons of certain ages would reasonably produce apprehension, and properties governed by deed restrictions or articles of incorporation.

43. Assembly Bill 1954, Cal. A. 1954, 1975-76 Reg. Sess. (1975), was proposed to ainend the antidiscrimination provisions of the Rumford Fair Housing Act, formerly found in $\$ \S 35700$ 35745 of the Health and Safety Code. The bill would have forbidden owners of certain size dwellings to refuse to lease accommodations because of the age of the applicant or the applicant's children. Exceptions included senior citizen housing and inobile home parks. Senate Bill 359, Cal. S. 359, 1977-78 Reg. Sess. (1977), was intended as an addition to the Unruh Act. This bill would have prohibited refusals to lease housing, discrimination in terms, conditions, privileges, services or facilities, and false representations regarding availability, when based solely on the fact that a minor child would occupy the premises. Nor could landlords require that, as a condition of continued tenancy, the tenants remain childless. The bill excepted senior citizen housing, college dormitories, and mobile home parks. Senate Bill 440, Cal. S. 440, 1979-80 Reg. Sess. (1979), and Assembly Bill 256, Cal. A. 256, 1981-82 Reg. Sess. (1981) both would have added to the Unruh Act provisions virtually identical to those of Senate Bill 359.

44. Three of the bills-Assembly Bills 1954, 3000, and 3409-were never voted on in committee. [1975-76 Reg. Sess.] 1 CaL. Assembly Final History 1105; [1977-78 Reg. Sess.] 2 CaL. AsSEMBLy FInal History 1691; [1979-80 Reg. Sess.] 2 CAL. AsSEMbly Final History 1922. Assembly Bill 2979 and Senate Bill 1688 were voted on, but failed to pass in committee. [1977-78 Reg. Sess.] 2 Cal. Assembly Final History 1681; [1977-78 Reg. Sess.] Cal. Senate Final HISTORY 917. Three Senate bills-359, 440, and 202-were forwarded froin committee to the 


\section{II \\ The UNRUH ACT AND "ARBITRARy Discrimination"}

While the Unruh Act encompasses both families with children, as protected "persons," 45 and lessors of rental housing, as regulated proprietors of "business establishments," a finding of discrimination against a person protected by the Act does not end the inquiry. Discrimination is permissible under the Act so long as it is not "arbitrary."46 In Marina Point the court erred in finding the "no children" policy to be arbitrary and therefore unlawful under the Unruh Act. There is convincing evidence that the Legislature never intended "no children" policies to constitute arbitrary discrimination, and the substantial interests of groups other than families with children dcmonstrate the reasonableness of such policies.

\section{A. Legislative Intent}

\section{Unpassed Bills As Evidence of Legislative Intent \\ a. The Court's Rejection of the Unpassed Bills}

The court mistakenly refused to consider that the nine unenacted bills $^{47}$ evidenced a legislative intent to exclude "no children" policies from the scope of arbitrary discrimination under the Unruh Act. Despite the fact that the bills were narrowly tailored to the subject of age discrimination in housing, the court dismissed these bills in a footnote as unpersuasive. ${ }^{48}$ To support its rejection of this evidence, the court cited Gay Law Students Association v. Pacific Telephone and Telegraph $\mathrm{Co}^{49}$ for the proposition that only very limited guidance as to legislative intent can generally be drawn from unpassed bills proposed to amend an existing statutory scheme. ${ }^{50}$ The Marina Point court found a

Senate, but failed to pass there. [1977-78 Reg. Sess.] CaL. SENATE FINAL History 229; [1979-80 Reg. Sess.] Cal. Senate Final History 280, 1151. The most recent bill, Assembly Bill 256, passed the Assembly but died in the inactive file of the Senate, where it had been placed at the request of the author pending the supreme court's decision in Marina Point. [1981-82 Reg. Sess.] I CAL. Assembly Final HISTORY 245; telephone conversation with Stephen Hopcraft, Legislative Coordinator for Lieutenant Governor Leo McCarthy, former assemblyman and author of Assembly Bill 256 (Mar. 2, 1983).

45. The court never clearly specified in Marina Point whether the "persons" it held protected by the Unruh Act were "children" or "families with children." See 30 Cal. 3d at 740, 640 P.2d at 126, 180 Cal. Rptr. at 508. Cf. id. at 744-45, 640 P.2d at 129, 180 Cal. Rptr. at 511 (Marina Point landlord "singl[ing] out children as a class for exclusion from shelter").

46. See supra text accompanying notes 36-38.

47. See supra text accompanying notes $41-44$.

48. 30 Cal. $3 d$ at 735 n.7, 640 P.2d at 123 n.7, 180 Cal.Rptr. at 504 n.7.

49. 24 Cal. 3d 458, 595 P.2d 592, 156 Cal. Rptr. 14 (1979).

50. 30 Cal. 3d at 735 n.7, 640 P.2d at 123 n.7, 180 Cal. Rptr. at 504 n.7 (citing Gay Law Students, 24 Cal. 3d at 480 n.13, 595 P.2d at 605-06 n.13, 156 Cal. Rptr. at 28 n.13). However, rather than suggesting that unpassed bills are generally of little use in deternnining legislative 
rationale for this proposition in an appellate court case, Sacramento Newspaper Guild v. Sacramento County Board of Supervisors, ${ }^{51}$ which suggested that unpassed legislation evokes too many conflicting inferences to be useful evidence of legislative intent. ${ }^{52}$

Contrary to the court's intimations, however, past cases suggest that there is no general presumption against use of unpassed bills in assessing legislative intent. ${ }^{53}$ Indeed, when assessing legislative intent, California courts have in some imstances relied heavily on legislative failure to enact a law. For example, in Cooper v. Swoap, ${ }^{54}$ the supreme court found the Legislature's rejection of a proposed amendment to the bill that later became the Welfare Reform Act the "most obvious" and "unambiguous" indication that the regulation at issue, which was very similar to the scheme proposed by the defeated amendment, was inconsistent with the Act. ${ }^{55}$

The court's reliance on Gay Law Students to support dismissal of the unpassed bills is troublesome because the circumstances of Gay Law Students presented a far stronger argument for disregarding unpassed bills than do the circumstances of Marina Point. In Gay Law Students, there was no need to refer to unpassed bills to determine legislative intent, because the statute at issue was clear on its face. Gay Law Students involved a public utility that had demurred to allegations of employment discrimination against homosexuals. The utility argued that the Public Utility Code's antidiscrimination provisions did not extend

intent, the cited passage in Gay Law Students actually recognized that "in some circumstances such legislative maction may represent a reliable indicant" of legislative intent. Id.

Indeed, California courts have typically placed heavy empliasis on the facts and circumstances of each case in determining the probative value of unpassed bills. See, e.g., Seibert v. Sears, Roebuck \& Co., 45 Cal. App. 3d 1, 19, 120 Cal. Rptr. 233, 247 (1975) (the "full context of circumstances in which the Legislature failed to enact any of the bills involved" persuaded the court to consider unpassed bills as evidence of legislative intent); Miles v. Workers' Compensation Appeals Bd., 67 Cal. App. 3d 243, 248 n.4, 136 Cal. Rptr. 508, 511 n.4 (1977) ("[I]n some legislative contexts, the rejection by the Legislature of a specific provision militates against a judgment that the Legislature intended a result it expressly declined to enact.").

51. 263 Cal. App. 2d 41, 69 Cal. Rptr. 480 (1968).

52. Marina Point, 30 Cal. 3d at 735 n.7, 640 P.2d at 123 n.7, 180 Cal. Rptr. at 505 n.7 (citing Sacramento Newspaper, $263 \mathrm{Cal}$. App. 2d at 58,69 Cal. Rptr. at 492).

53. The fact that unpassed bills arise in legislative sessions postdating the enactment of the legislation to be interpreted does not seein to trouble the courts. See generally Willard \& MacDonald, The Effect of An Unsuccessful Attempt to Amend a Statute, 44 CoRnell L.Q. 336 (1958). Rather, as in Sacramento Newspaper, it is the conflicting inferences arising from these subsequent unpassed bills that creates reluctance to employ the unpassed bills as a means of assessing legislative intent.

54. 11 Cal. 3d 856, 524 P.2d 97, 115 Cal. Rptr. 1 (1974).

55. Id. at 863-64, 524 P.2d at 101-02, 115 Cal. Rptr. at 5-6. See also Nestle v. City of Santa Momica, 6 Cal. 3d 920, 935-36, 496 P.2d 480, 490, 101 Cal. Rptr. 568, 578 (1972) (Where a provision immunizing the government from nuisance claims was deleted from an eventually successful bill, the deletion was dispositive evidence of legislative intent that nuisance actions against the govcrnment be permitted.). 
to employment matters. To support its contention, the utility pointed to two unpassed bills that would have added "employment" to the Code's list of impermissible areas of discrimination. The statute that was to be alnended by the bills, however, already expressly prohibited utilities from arbitrarily discriminating not only in the several enumerated ways, but also "in any other respect." 56 Given the force of the statute's existing language, the court decided it was unrealistic to rely on two unpassed bills proposed fifty-seven years after the statute was enacted to argue that employment discrimination was not intended to be prohibited under the section. ${ }^{57}$ In Marina Point, by comparison, the court could not derive froin the statutory language any persuasive evidence concerning whether the Legislature intended housing discrimination against children to be treated as arbitrary under the Unruh Act, because the Act does not define what constitutes the arbitrary discrimination it forbids. The unenacted legislation specifically addressing the issue before the court was the best available evidence of the intended scope of the Act.

The court's reliance on the rationale provided by Sacramento Newspaper is also problenatic because that rationale fails when applied to the facts of Marina Point. Relying on Sacramento Newspaper's view that the existence of unpassed legislation is too ainbiguous to be useful evidence of legislative intent, ${ }^{58}$ the court in Marina Point suggested that the failure to enact the nine age discrimination bills might reflect no more than the Legislature's belief that such discrimination was already prohibited under the Unruh Act, and that there was no

56. See Cal. Pub. Util. Code $\S 453$ (West 1975).

57. Gay Law Students, $24 \mathrm{Cal}$. 3d at 480 n.13, 595 P.2d at $605-06$ n.13, 156 Cal. Rptr. at 28, n.13. The court in Gay Law Students also identified a strong line of common law authority prohibiting monopolistic industries (such as utilities) from arbitrarily discriminating in cmployment matters. The court found this precedent further supported a broad reading of the statute's language. Id. at 480-83, 595 P.2d at 606-08, 156 Cal. Rptr. at 28-30.

The unpassed bills found unpersuasive in Gay Law Students can be distinguished from those relevant to Marina Point on yet another ground. The two unpassed bills cited in Gay Law Students were introduced in the same year and were identically worded. See Cal. A. 195, 1971-72 Reg. Sess. (1972); and Cal. S. 333, 1971-72 Reg. Sess. (1972). In contrast, the nine bills imphicated in Marina Point represented an unsuccessful effort spanning several years to eliminate various forms of age discrimination in housing, and presented legislators with an array of provisions, some less restrictive of landlord rights than others. See supra notes 41-43 and accompanying text. Moreover, in contrast to the fifty-seven year spread betweeu the legislation and the proposed amendments in Gay Law Students, the bills in Marina Point closely followed the legislature's 1974 reenactment of the Unruh Act that incorporated the Cox construction. See supra note 38 and accounpanying text.

58.

The unpassed bills of later legislative sessions evoke conflicting inferences. Some legislators might propose them to replace an existing prohibition; others to clarify an existing permission. A third group of legislators might oppose them to preserve an existing prohibition, and a fourth because there was no need to clarify an existing permission.

Sacramento Newspaper, 263 Cal. App. 2d at 58, 69 Cal. Rptr. at 492. 
need to clarify that proscription..$^{59}$ Alternatively, it suggested that the failure to enact the bills might have been attributable, not to disagreement over a prohibition of discrimination against children in housing, but to disagreenent over the nature of the exceptions to the antidiscrimination provisions listed in the various bills. ${ }^{60}$

Neither of these explanations is consistent witl the circumstances surrounding the failure of the Legislature to enact the age discrimination bills. First, as will be shown below, there is substantial evidence that, in fact, the Legislature did not understand age discrimination to be prohibited under the Act. ${ }^{61}$ Second, the nature of the exceptions in several of the unpassed bills renders it unlikely that the legislators would object to the exceptions listed. For instance, Senate Bill 359, designed to annend the Unruh Act to prohibit discrimination based on the presence of a minor child in the potential tenant's household, excepted only college dormitories, housing designed for senior citizens, and mobile loone parks-facilities few would argue need to be open to children. ${ }^{62}$ Yet the bill was defeated in the Senate. ${ }^{63}$

\section{b. The Nine Unpassed Bills}

Between 1975 and 1981, the legislature sought nine times to enact soine variant of the rule later judicially imposed by the supreine court in Marina Point ${ }^{64}$ The numerous legislative attempts to prevent landlords from discriminating on the basis of age give rise to a strong inference that the lcgislature did not believe such policies to be prohibited under existing law. Had the legislators believed that such policies were already prohibited, it is unlikely that they would have continued to pursue, time and time again, efforts that would inerely duplicate existing law. ${ }^{65}$ Alternatively, if the bills were designed only to clarify ex-

59. 30 Cal. $3 d$ at 735 n.7, 640 P.2d at 123 n.7, 180 Cal. Rptr. at 505 n.7.

60. $I d$.

61. See infra notes 65-68.

62. See supra note 43 . The mobile home parks exception may well derive from the special nature of these parks, which, as the court noted in Marina Point, have features that make them particularly suitable for residency by senior citizens. 30 Cal. $3 \mathrm{~d}$ at $743 \mathrm{n} .11,640$ P.2d at $128 \mathrm{n} .11$, $180 \mathrm{Cal} . \mathrm{Rptr}$. at 510 n.11.

63. See supra note 44.

64. See supra notes $41-44$.

65. The court has implicitly recognized that the number of attempts made to enact certain legislation is a factor to be considered in assessing the persuasiveness of unpassed bills as evidence of legislative intent. See Agricultural Labor Relations Bd. v. Superior Court, 16 Cal. 3d 392, 41718, 546 P.2d 687, 704-05, 128 Cal. Rptr. 183, 200-01 (1976) (rejecting as evidence of legislative intent a single unpassed bill) (distinguishing Cooper v. Swoap, 11 Cal. 3d 856, 524 P.2d 97, 115 Cal. Rptr. 1 (1974), where "three successive attempts [were made] to add a certaim provision," and Clean Air Constituency v. California State Air Resources Bd., 11 Cal. 3d 801, 523 P.2d 617, 114 Cal. Rptr. 577 (1974), where the legislature "rejected no less than five proposals"). 
isting law, ${ }^{66}$ it is probable that writings associated with the bills would have provided explicit evidence of this design; by characterizing the bills as clarifications, proponents could presumably expect to minimize opposition to their passage. But no such statements exist. By coinparison, the sponsoring committee of the 1974 bill that added "sex" to the Unruh Act's enumeration of protected classes indicated that the bill's purpose was merely "to bring it to the attention of the legal profession that the Unruh Act [already] provides a remedy for arbitrary discrimination against woinen (or men) in . . . business enterprises." 67 Finally, various writings associated with the unpassed bills provide explicit support for the inference. For example, a meinorandum circulated in conjunction with Asseinbly Bill 256 stated that in contrast to the protection against housing discrimination afforded to persons on the basis of characteristics such as race or sex, "[F]amilies with children have yet to be granted the very same basic protection." 68

66. If the legislature truly intended the Unruh Act to prohibit policies such as Marina Point's, a clarification of the law was certainly in order. Studies liave deinonstrated that landlords frequently impose age restrictions on tenants. Marina Point, 30 Cal. 3d at 729 n.1, 640 P.2d at 119 n.1, 180 Cal. Rptr. at 501 n.1. These practices are so common that they could hardly have escaped the notice of the legislature. It is also reasonable to assume the legislature was aware of the 1971 Flowers decision, which found a landlord's policy against renting to families with boys over five years of age to be reasonable and therefore permissible under the Unrulh Act. 21 Cal. App. 3d 700, 98 Cal. Rptr. 644 (1971). In fact, in 1975 the California Attorney General was asked by a state senator to render an opinion about the permissibility of rental lousing discrimination on the basis of factors that included the number of children in a potential tenant's family. $58 \mathrm{Cal}$. Op. Att'y Gen. 608 (1975). The published opinion diseussed Flowers extensively, and concluded that such discrimination was permissible as long as circumstances demonstrated it was not arbitrary. The attorney geueral opined that the determination of whether a certain practice was arbitrary inight depend on such factors as the nature of the property and the number of children. Id. at 613 . Had the legislature disagreed with Flowers or the Attorney General's construction of the Unruh Act, it presumably would have taken steps to correct the misunderstandings. Its failure to do so leads once again to the inference that it did not believe such discrimination to be prohibited.

67. See Marina Point, 30 Cal. 3d at 734, 640 P.2d at 122-23, 180 Cal. Rptr. at 503-04.

68. Meinorandum from Christine Minnelian, Department of Housing and Community Development, to Honorable Members of the Assembly Housing and Community Development Committee (n.d.) (on file with the California Law Review). Statements contained in some of the Legislative Counsel's Digest summaries that accompanied the text of the proposed bills also support the inference that such discrimination was not prohibited before Marina Point. For instance, the Digest accompanying Assembly Bill 256 stated that statutory law existing as of January 1981, "does not prohibit discrimination because [a potential tenant] has a minor child. This bill would make [such discrimination] unlawful . . . Cal A. 256, legis. counsel's digest, 1981-82 Reg. Sess. (1981) (Mar. 23, 1981) (emplrasis added). See also Cal A. 1954, legis. counsel's digest, 197576 Reg. Sess. (1975) (Apr. 17, 1975) ("This bill would extend [the] rights and remedies fof persons denied full and equal accommodations in business establishments] to denials based on age.") (cmplrasis added).

A later version of the Digest for Assenibly Bill 256 added the word "specifically" before "prohibit." Cal. A. 256, legis. counsel's digest, 1981-82 Reg. Sess. (as anrended by Cal. Senate Aug. 10, 1981). Although this alteration might be read to say that while not specifically histed in the statute, such discrimination was nonetheless prohibited by the Unruh Act, circumstances suggest the alteration may lave been otherwise motivated. The bill's authors, aware that the California Supreme Court had granted a hearing in Marina Point, see supra note 44, may have realized 


\section{Evidence Provided by the FEHA}

The California Fair Employment and Housing Act ${ }^{69}$ (FEHA) provides further evidence that the California Legislature has never intended to prohibit discrimination against minor children in housing. The FEHA omits age froin its hist of forbidden criteria in selecting tenants. $^{70}$ In stark contrast, it states in several provisions that certain types of age discrimination will not be tolerated in the field of employinent. ${ }^{71}$ Indeed, within the single provision that articulates the public policies and legislative intent behind the FEHA, the drafters included age as one of eleven prohibited bases of discrimination in the field of employment, yet omitted age as a prohibited basis of discrimination in housimg. ${ }^{72}$ These provisions reveal the clear theme of the Act: While certain age discrimination is forbidden in employment matters, it is not prohibited in the provision of housing. The difference in the protection afforded by the statute in these two areas could not possibly have escaped the notice of the legislature, which can therefore be deemed to have approved of the distinction.

\section{B. Assessing the Interests}

In Marina Point, the court seemed to define the arbitrary discrimination prohibited under the Unruh Act as exclusion of persons based on class membership, rather than based on individual behavior. ${ }^{73}$ But the court's suggestion that class-based exclusions are always arbitrary-and thus impermissible under the Act-is ultimately untenable. Classifications based on age have long been treated differently from those based on such criteria as sex or race. Policies that discriminate on the basis of age, especially policies that discriminate against children,

that the earlier version of the Digest could constitute evidence of legislative intent to allow "no children" policies. The bill's authors, however, wanted such policies to be prohibited.

69. The Fair Employment and Housing Act, CAL. Gov'T CoDE $\$ \$ 12900-12996$ (West 1980) contains substantially the sane prohibitions against housing discrimination as did its predecessor, the Fair Housing Law, CAL. HeALTH \& SAFETY CODE $\$ \S 35700-35745$ (repealed 1980), which was in effect when suit was filed in Marina Point. Compare CAL. Gov'T CoDE $\$ 12955$ (West 1980) with CAL. Health \& SAFETY Code $§ 35720$, as amended by Act of Sept. 30, 1975, ch. 1189, §§ 3, 3.5, 1975 Cal. Stat. 2942, 2943-45 (repealed 1980). In Marina Point, the court refused to consider the limited protection afforded by the provisions of the FEHA, $30 \mathrm{Cal} .3 \mathrm{~d}$ at $731 \mathrm{n.5}, 640 \mathrm{P.2d}$ at 121 n.5, 180 Cal. Rptr. at 502, n.5 (citing $\$ 35743$ of the Health and Safety Code, now codified at CAL. Gov'T CODE $\$ 12993$ ("Nothing contained in this part shall be construed to . . . limit the application of [the Unruh Act].")). However, this provision is better read to mean that discrimination claims can be brought under either statute. 1980).

70. CAL. Gov'T CoDE $\S 12955$ (West 1980). See also id. $\$ \S 12920,12930(\mathrm{i}), 12935$ (g) (West

71. E.g., id. $\$ \S 12920,12921,12941$. However, only that employment discrimination that is directed against persons over age forty is outlawed. See id. \$\$ 12926(a), 12941.

72. Id. $\S 12920$.

73. See supra text accompanying notes 18-21. 
are commonly accepted in our society, and courts have sanctioned such distinctions. $^{74}$

Age classifications are found in a number of California statutes that operate to impose differential treatment on children. ${ }^{75}$ Most of the lines drawn by such statutes are indisputably "arbitrary," in the sense apparently intended by the court in Marina Point. ${ }^{76}$ There is no room for individual assessment in laws that, for example, deny to twentyyear-olds the privilege of buymg liquor, ${ }^{77}$ or restrict the age at which one may be held to have entered into an enforceable contract. ${ }^{78}$ While many of these laws might be justified as necessary to protect children from unwholesome influences, some cannot be rationalized on that basis alone and reflect more concern for the rights of others than for the interests of minors. This latter class includes statutes that restrict driving licenses and voting rights to persons of certam ages, ${ }^{79}$ or that limit admission to public schools to children who have reached a certain age. ${ }^{80}$ The existence of these laws deinonstrates society's tolerance for "arbitrary" discriminations of this sort. But it is also apparent from statutes such as these that in fashioning laws and policies that restrict the rights of mimors, the legislature has not been concerned with the behavior or maturity of a particular child. Rather, these laws reflect legislative determinations that, in many contexts, it is reasonable to restrict the rights of children as a class where there are substantial conflicting interests. ${ }^{81}$

74. See, e.g., Prince v. Massachusetts, 321 U.S. 158 (1944). In Prince, the Court upheld a statute prohibiting a boy under twelve or a girl under eighteen from selling newspapers or merchandise in public places. Dismissing a challenge brought on behalf of a child who believed it her religious duty to perform this work, the Court stated: “The state's authority over children's activities is broader than over like actions of adults." Id. at 168. See also Ginsberg v. New York, 390 U.S. 629 (1968) (upholding a statute according minors a more restricted right than that assured to adults to determine for themselves what sexual material they may read or view).

75. See, e.g., CAL. PENAL CODE $\$ 26$ (West 1970) (capacity of a child under the age of 14 to commit crimes requires proof that the child knew of the act's wrongfulness at time of commission); id. $\$ 308$ (making it a misdemeanor to sell tobacco to a person under the age of 18); CAL. CIv. CODE $\$ 25.5$ (West 1982) (minor must be at least 17 years of age to consent independently to the donation of his or her blood).

76. See supra text accompanying notes 18-21.

77. E.g., CAL. Bus. \& Prof. CoDe $\$ 25658$ (West 1964).

78. E.g., CAL. CIv. CODE $\$ 35$ (West 1982).

79. E.g., CAL. VEH. CODE $\$ 12512$ (West 1971); CAL. Const. art. 2, § 2.

80. E.g., CAl. Educ. CODE $\S \S 48000,48010$ (West 1978). The rights and interests of nonminors are also recognized and accominodated in less formal, but cominonly encountered policies. Such policies include the exclusion of children, unless accompanied by adults, from stores openly displaying fragile inerchandise, and froin swimming pools during "adults only" swim periods; and the exclusion of minors froin discotheques, bars, and "adults only" health clubs.

81. Moreover, distinctions drawn on the basis of a child's age impose only temporary restrictions on rights or privileges; such restrictions can only last until the child reaches a certain age. In this sense, such discrimination is inherently more reasonable than, for instance, racial or sexual discrimination. 
Inconsistencies in the Marina Point opinion refiect the court's uncertainty as to the validity of einploying its definition of "arbitrary" in the context of age discrimination. Had the court beheved all classbased discrimination to be inipermissible, its analysis should have ended upon finding that the landlord's "no children" policy was classbased. Yet the court proceeded to review separately the "reasonableness" of the policy, and concluded that the landlord's policy could not be so justified. ${ }^{82}$ In a further inconsistency, the court acknowledged, in dicta, that the exclusionary policies of privately owned coinplexes reserved for older persons are "reasonable and permissible" under the Unruh Act. ${ }^{83}$ Yet such exclusionary policies are just as "arbitrary," under the court's definition, as those of complexes reserved for adults generally.

The nature and weight of the conflicting interests at stake in $\mathrm{Ma}$ rina Point deinonstrate that "no children" pohcies are not unreasonable. One interest is that of adult renters who are childless or whose children no longer hive at hoine. As Justice Richardson pointed out in his Marina Point dissent, adults, particularly those who have worked a number of years or have finished raising their own families, should be able to live in a quiet, peaceful environment if they so desire, away from the noise and disruption of children. ${ }^{84}$

Another interest is that of the owner of the apartment complex. Disallowing discrimination against children infringes upon the apartment owner's property rights. First, the presence of children in apartment complexes normally serves to impose a higher standard of care upon landlords to take precautions to eliminate potentially dangerous conditions. ${ }^{85}$ Adults generally perceive dangers more readily than do

82. 30 Cal. 3d at 741-44, 750 P.2d at 127-29, 180 Cal. Rptr. at 509-11. See supra text accompanying notes 22-24. The court's rejection of the policy as unreasonable may well have reflected a failure to adhere to the correct standard of review. As the dissenting justices noted in Marina Point, the trial court's findings of fact appeared to be amply supported by the evidence, which showed dangers posed by the facilities at the complex, as well as a lack of recreational facilities appropriate for children. $30 \mathrm{Cal}$. 3d at 746-47, 640 P.2d at 130-31, 180 Cal. Rptr. at 512 (Richardson, J., dissenting). Alternatively, the court may have implicitly adopted a new rule requiring more than a "rational relationship" between a landlord's exclusion of children and his interest in reducing safety hazards or preserving facilities for their proper use.

83. 30 Cal. 3d at 742-43, 640 P.2d at 127-28, 180 Cal. Rptr. at 509-10. The court reasoned that Marina Point's rule did not serve a societal interest as significant as that served by the exclusionary policies of complexes reserved for the elderly, $i d$. at 743,640 P.2d at 128-29, 180 Cal. Rptr. at 510; but such reasoning fails to explain why the court allows complexes for the elderly to exclude the non-elderly as a class. Nor did the court explain why it believed that only the most compelling interests suffice to make age discrimination "reasonable" under the Unruh Act.

84. 30 Cal. 3d at 745, 640 P.2d at 130, 180 Cal. Rptr. at 511 (Richardson, J., dissenting). See also Note, Housing Discrimination Against Children: The Legal Status of a Growing Social Problem, 16 J. FAM. L. 559, 560-61 (1977-78).

85. See generally W. PROSSER, HANDBOOK OF THE LAW OF TORTS §33, at 170-73 (4th ed. 1971) (discussing duty of reasonable man to anticipate and guard against the conduct of others). 
children, who are also more curious and mischievous and thus less likely to avoid dangerous situations. Moreover, because children are held to a lower standard of care than are adults, children are less likely to be found contributorily neghigent. ${ }^{86}$ Therefore, landlords who allow children encounter a risk of greater hability than those who exclude children. This is an important consideration im all cases, but especially where, as at Marina Point, the facilities pose special dangers to young tenants. ${ }^{87}$ Second, there is evidence that children generally imflict unore wear and tear on property than do adults, and that consequently, landlords who rent to families with children are likely to have higher maintenance costs than those who do not. ${ }^{88}$ Third, a landlord inay wish to have a homogeneous group of tenants to avoid increased costs resulting from high turnover caused by incoinpatibility annong tenants. High turnover results in increased expense to the landlord who rehabilitates his rental units between tenancies and nnay also generate higher administrative costs. Given the legitimate interests of the childless adult and the apartment owner, and the rational relationship of these interests to a "no children" policy, the court unjustifiably deened the Marina Point policy violative of the Unruh Act.

\section{III}

\section{Enforcement Problems and Alternative Remedies}

\section{A. Enforcing Marina Point}

Because Marina Point will be almost impossible to enforce, it will be of limited use im remedying the problem it addresses. The costs and burdens of litigation are one obvious obstacle to effective enforcement of the decision. ${ }^{89}$ These costs and burdens are likely to deter most

See also, e.g., Roberts v. Del Monte Properties Co., 111 Cal. App. 2d 69, 243 P.2d 914 (1952) (affirming jury verdict against hotel owner for injuries received by seven-year-old who climbed up to play on furniture stacked near open window and fell out).

86. Children are held only to that degree of care normally exercised by children of the same age under similar circumstances. Ellis v. D'Angelo, 116 Cal. App. 2d 310, 315, 253 P.2d 675, 678 (1953). Moreover, children under four years of age are normally held incapable, as a matter of law, of being contributorily negligent. Id. at 315-16, 253 P.2d at 678. See also Alvarado v. Anderson, 175 Cal. App. 2d 166, 177, 346 P.2d 73, 80 (1959) (affirming jury verdict for thirteen-year-old injured by broken diving board, stating: "Knowledge of the existence of a danger under circumstances where it might bar an adult from recovery, does not, as a matter of law, [always] bar a child.").

87. See supra note 6.

88. Marina Point, $30 \mathrm{Cal}$. 3d at 728, 640 P.2d at 119, $180 \mathrm{Cal}$ Rptr. at 500. See also Note, supra note 84, at 563.

89. More than 1,300 cases of discrimination against children in housing were reported to the Fair Employment and Housing Practices Commission between April 1982 and March 1983. The Commission, one potential source of aid to Unruh Act claimants, has been unable to handle the vast number of clains. But its efforts have included informing apartment owners and newspapers about the illegality of discrimination against families with children in rental housing. See Bishop, 
plaintiffs from filing suit even in those rare instances where a landlord admits potential tenants were turned away solely because they had a child.

The larger problem may well be the variety of means that remain available to a landlord interested in circumventing the law. Perhaps the easiest course for the landlord is simply to continue to discriminate, albeit covertly. The landlord often chooses from a number of potential tenants. Where a landlord provides no explanation, or where he provides a false but "legitimate" reason for refusal to lease, little prevents him from choosing childless tenants over a family. It will be extremely difficult for persons challenging a landlord's denial of accommodations to prove that, but for the presence of a minor child in their household, they would have been selected as tenants. ${ }^{90}$

Moreover, even if a landlord ostensibly opens his doors to tenants of all ages, he may employ creative means to discourage families with children from moving in. ${ }^{91}$ For example, developers of new apartments can deter family occupancy by providing fewer bedrooms, or by designing grounds without play areas. The landlord himself can institute regulations that require parents to supervise their children. Limiting access of children to recreational facilities in the complex unay make parents unwilling to pay the additional rental expense attributable to such amenities. ${ }^{92}$ Incremental rent increases for each additional

'Creative' Rules for Adults-Only Rentals, CAL. J., Mar. 1983, at 126. If the new rule is to be effectively enforced through the courts, additional state funding would seem to be required.

Moreover, while the damages provisions of California Civil Code $\S 52$ provide some incentive to Unruh Act plaimtiffs, the risk of losing sums invested in hitigation, coupled with the frequent difficulty of proving discrimination, will discourage most would-be challengers. See infra text accompanying note 90 .

90. An Unruh Act plaintiff can attempt to prove discrimination by presenting evidence establishing a pattern of discriminatory conduct. CAL. CIv. CODE $\$ 52$ (West 1982). But where the landlord who "arbitrarily" discriminates against the plaintiff has previously accepted soine children as tenants, this method of proof is likely to fail. On the other hand, Marina Point's rule inay be more useful where the challenged action is an eviction or refusal to renew a lease because of the birth or adoption of a child. If the landlord is unable to prove there was good reason for his action, it will be easier to prove discrimination.

91. See generally Bishop, supra note 89, at 126; A Hard Look/Many Landlords Still Banning Kids, San Francisco Examiner, May 15, 1983, at A, col. 2.

92. Landlords soinetimes deny unaccompanied children the right to use common facilities such as recreation rooms, or specify pool hours which coimcide strategically with the hours children are in school. Some landlords also impose regulations to limit the activity of children, such as prohibiting tricycle riding or frisbee throwing. Bishop, supra note 89 , at 126 . In addition, facilities offered by an apartincnt complex can be withheld from children whenever the facilities pose a danger to the children's safety. See Marina Point, 30 Cal. 3d at 744, 640 P.2d at 129, 180 Cal. Rptr. at 510 . By invoking safety concerns, landlords can also prohibit children from occupying units near a pool or above the first floor. This strategy would allow a landlord to create "adults only" sections of the building while also reducing the total number of children in the complex. 
occupant, or restrictions on the number of persons permitted to occupy an apartment, may also dissuade families with children.

\section{B. Remedying the Problem}

A judicially imposed rule prohibiting landlords from excluding children is the most intrusive and inflexible way to treat the problem of family housing shortages, and is unlikely to produce the desired results. ${ }^{93}$ A inore effective, fair, and farsighted means requires legislation that expressly abrogates Marina Point and directs local governments to take action to resolve the problem. ${ }^{94}$ California's local planning statute, complete with mechanisms to ensure citizen input, local supervision, and state review, would, with some modification, solve the problem of family housing shortages.

\section{A Proposal}

California's local planning statute ${ }^{95}$ requires each county and city to develop a general plan consistimg of nine "elements," or subplans, that address various problems. ${ }^{96}$ The legislature, deeming "decent housing and a suitable hiving environment for every Cahfornia family . . . a priority of the highest order,"97 has included a housing plan as the newest of the nime required eleinents. ${ }^{98}$ The housing eleinent of every county and city must "identify adequate sites for housing . . . and shall make adequate provision for the existing and projected needs of all economic segments of the community." 99 The statute includes

93. See supra text accompanying notes 89-92.

94. Although the California Legislature may not need to abrogate Marina Point in order for local governments to initiate certain programs to alleviate housing shortages, this Note suggests that it do so. Because the legislature has found the housing shortage problem to be "of vital statewide importance," CAL. Gov'T CoDE $\$ 65580$ (a) (West 1983), local governments can pass ordmances to cope with the problem only to the extent they do not conflict with or duphicate general laws. See CAL. Const. art. XI, § 7; Pipoly v. Benson, 20 Cal. 2d 366, 370-71, 125 P.2d $482,484-85$ (1942). Under this rule, local ordinances allowing soine exclusion of families from rental housing will likely be held invalid as conflicting with Marina Point's construetion of the Unruh Act; ordinances prohibiting discrimination in rental housing against families with chidren could be struck down as duphicative. See generally Comment, Local Attempts to Ban Discrimination in Rental Housing Against Families with Children: Avoiding the Preemption Barrier, 17 SAN Diego L. REv. 403, 410-27 (1980). Therefore, to provide local governments with the widest choice of measures to coinbat the housing problein, the legislature should expressly abrogate the court's decision.

95. CaL. Gov't CODE $§ \S 65100-65761$ (West 1983).

96. Id. $\S \S 65300.5-65307$. Required elements are: (1) land use; (2) circulation; (3) housing; (4) construction; (5) open-space; (6) seisunic safety; (7) noise; (8) scenic highways; and (9) safety. Id. $\$ 65302$.

97. Id. $\$ 65580(\mathrm{a})$.

98. Id. $\S \S 65580-65589$, added by Act of Sept. 26, 1980, ch. 1143, § 3, 1980 Cal. Stat. 3694, 3697-3703.

99. Id. $\S 65583$. Each locality's housing element must provide not only for the needs of the 
provisions for local hearings, so that citizens may participate in the decisionmaking process, and for state level review of local implementation. Amending the local planining statute to require each locahity to assess and plan for the specific housing needs of families with children would go far to ensure adequate housing opportunities to families with children. ${ }^{100}$

The planning statute, amended as proposed by this Note, provides localities with a choice of means to remedy housing shortages for famihes with children. While local zoning ordimances must be consistent with the plans developed under the statute, ${ }^{101}$ the law does not specify the steps to be taken to accomplish the plan's goals. Those communities believing the Marina Point rule to be the best remedy for the local housing problem may implement the rule by local ordinance. ${ }^{102}$ Other locahities may prefer less drastic remedies, such as requiring landlords to set aside certam portions of their buildimgs for childless adults and other portions for families with children. ${ }^{103}$

community, but also for the locality's share of the regional need for housing for persons of all economic levels. Id $\S 65584$. Three components are required: (1) an assessment of resources and constraints relevant to the goal of meeting the needs of all economic seginents; (2) a statement of the community's goals and quantified objectivcs regarding the development of housing opportunities; and (3) a program setting forth a five-year schedule of actions for the impleinentation of the declared goals. Id. $\S 65583$.

100. Under the current statute, no analysis of the special needs of families with children is mandated. The statute's requirement that locahities plan for housing affordable to all economic segments of the community will not necessarily solve the housing shortage facing these families; housing opportunities are not always dependent upon a family's ability to pay, especially in a tight rental market. Rather, given a number of potential tenants equally capable of paying the proposed rent, landlords may still prefer to lease to adults without children. See supra text accompanying notes 85-88.

101. Cal. Gov'T CoDE $\$ 65860$ (a) (West 1983).

102. Prior to Marina Point, the cities of Los Angeles, Santa Monica, Davis, and Berkeley eaclr adopted such ordinances, as did the City and County of San Francisco and the County of Santa Clara. Holmes \& Brown, The Age Restricted Residence: Legitimate Exclusionary Zoning For the Future, 13 LoY. L.A.L. REv. 921,949 (1980). The Berkeley ordinance provided in relevant part: It is unlawful for the owner . . . or other person having the . . . right to rent or lease any housing accomodation ... to:

A. Refuse to rent or lease ... [to] any person such accomodations because of the potential tenancy of a mimor child or children;

B. Represent to any person because of the potential tenancy of a minor child or children that housing accominodations are not available for inspection or rental when such dwelling is in fact so available;

C. Make, print or publisl ... any notice . . . with respect to the rental of housing accomdations that indicates any preference limitation or discrimination toward a person based on the poteutial tenancy of a mimor child or children;

D. Discriminate against any person in the terms and conditions of rental housing accomodations or in the provision of services or facilities in comection therewith.

Berkeley, Cal., Municipal Code $§ 13.24 .030$ (1980).

Any person who wilfully violates the provisions of the ordinance is liable for $\$ 500$ in damages plus reasonable attorney's fees and costs. Id. $\S 13.24 .060$.

103. See Dunaway \& Blied, Discrimination Against Children in Rental Housing: A California Perspective, 19 SANTA Clara L. Rev. 21, 50 (1979). Another alternative would be to impose a 
Of appeal to some communities may be a program to mcrease the stock of housmg designed especially for families with children. This approach offers two advantages. First, construction of new family-oriented housmg would contribute to an overall increase in the housing supply. Second, by providimg new housmg opportunities especially for families with children, the demand made by these families upon the general housing market would decrease, permitting other coinplexes to reserve their facilities for adults. This program would accommodate the interests of a broader range of citizens.

\section{Advantages of the Proposal}

The primary benefit of the proposal advanced is that it delegates to local governments the responsiblity for choosing a solution to the problem of housmg shortages for families with children. This delegation results in both inore effective interest balancing and greater flexibility in fashioning remedies. Formulation of the best solution to the problem of providing adequate housing for all inembers of society requires a fair accommodation of the interests of many groups. Any law governing "adults only" apartment buildings will in sonve way affect landlords, developers, families with children, and childless adults. Local governments can assess these often conflicting interests inore accurately than can state government or the courts, because local governinents are familiar with the local housmg inarket, community deinographics and needs, local economic factors, and the problems that have arisen from existing housing arrangements.

Next, the proposal allows each local government the flexibility to choose that solution best suited to the locality's features and needs. The severity of the housing shortage facing families with children varies by locality. ${ }^{104}$ This geographical variation deinands a flexibility in treatment that a broad rule, such as that imposed by Marina Point, cannot provide. Local governments can thus fashion solutions which are more closely tailored to local conditions and which more fairly ac-

blanket local prohibition on discrimination against families with children, but to allow apartment owners to petition the local planning agency for a waiver. In determining whether to grant the waiver, the agency would be required to consider such factors as the size, location, and nature of the apartment's facilities, including their relative suitability for occupation by families with children, and to balance these considerations against the urgency of the local need for faunily housing. The local government could also impose a ceiling on the nuuber of units granted waivers.

104. Even among urban localities, the severity of the housing shortage varies significantly. See generally The FaIR Housing Project, The Extent ANd EFfects of Discrimination Against Children in Rental Housng-A Study of Five California Cities 17 (1979), reprinted in Application for Leave to File Amicus Curiae Brief by Fair Housing for Children Coalition, Inc. in Support of Defendants and Appellants at 50 app, Marina Point, Ltd. v. Wolfson, 30 Cal. 3d 721, 640 P.2d 115, 180 Cal. Rptr. 496 (1982) (No. L.A. 31199) (on file with the California Law Review). 
commodate all the interests involved. ${ }^{105}$ State government and the courts, in contrast, can only make rules of general application, which often fail to consider the specific needs of individual communities. ${ }^{106}$

The proposal also provides an opportunity for increased communication between the "regulator" and the "regulatee." The existing planning statute requires local learings where citizens can comment upon proposed actions and raise concerns that may not otherwise liave been adequately considered. ${ }^{107}$ In turn, these hearings may increase public support as well as promote increased understanding among decisionmakers, tenants, landlords, and developers, resulting in enhanced cooperation and compliance with the local regulation.

Finally, the proposal ensures both the efficiency and effectiveness of local efforts to assess and remedy liousing shortages for families witl children. It treats the problem througln an existing scheme with which local officials are already familiar. Because it incorporates this existing scheme, the proposal requires ongoing local supervision and modification of housing plans to accommodate clianges in local conditions. ${ }^{108}$ The proposal also provides for review of the housing plans at the state level, ${ }^{109}$ and affords interested parties the opportunity to bring actions to ensure that both the housing plans and any zoning actions taken by the local government conforin with state planning requirements. ${ }^{110}$ Consequently, localities will encounter difficulties if they attempt to avoid their responsibility to promote lousing opportunities for families with children.

\section{ConCLusion}

In Marina Point v. Wolfson, the California Supreme Court lield that the Unruh Civil Rights Act prohibits discrimination against families with children in the rental of housing accommodations. In reaching this decision, the court overlooked evidence that the California

105. The legislature has formally recognized the superior ability of local governments to determine what efforts are required to fulfill the need for housing. See CAL. Gov'T CoDE $\$ 65581$ (c) (West 1983).

106. Coinmentators have also noted that state legislation to solve the problem of family housing shortages has met with only limited success in other states and presents a greater danger of social and political backlasli than does local action. Dunaway \& Blied, supra note 103, at 48-49. Regulation by local ordinances provides the further advantage of allowing repeal of restrictive measures as soon as the housing shortage lias abated within the locality.

107. CAL. Gov't CodE $\$ \S 65351,65355,65356.1$ (West 1983). See also id. $\$ \S 65304$, 65400 (c)-(d).

108. Id. $\$ 65588$.

109. Id. $\$ 65585(\mathrm{~b})$-(d); CAL. HEALTH \& SAFETY CODE $\$ 50459$ (West 1979). Local legislative bodies must consider the state agency findings prior to adopting or revising the element. $C_{A L}$. Gov'r CODE § 65585(b) (West 1983).

110. CaL. Gov'T CoDE $\S \S 65301.5,65587$ (West 1983). 
Legislature did not intend such a prohibition to fall within the scope of the Act, and failed to recognize the interests that suggest the reasonableness of "no children" policies. A better remedy to the problem of housing shortages for families with children is to shift to local governinents the responsibility for designing solutions tailored to their communities' needs. Local governments are well-equipped to identify and accommodate the competing interests in a politically responsive inanner.

Susan Ann Miles"

* A.B. 1931, Stanford University; third-year student, Boalt Hall School of Law, University of California, Berkeley. 


\section{ADDENDUM}

Shortly after this Note was written, the California Supreme Court issued its decision in $O^{\prime}$ Connor $v$. Village Green Owners Association, ${ }^{111}$ holding invalid and unenforceable a condominium development's covenants, conditions, and restrictions that limited residency to persons over the age of eighteen. The court lield that the condominium owners association was a "business establishment" withm the ineaning of the Unrulr $\mathrm{Act}^{112}$ and was therefore prevented by the ruling in Marina Point from imposmg age restrictions on occupancy. ${ }^{13}$

In a dissenting opinion in which Justice Richardson concurred, Justice Mosk criticized the majority for "legislat[ing] in a field-age preference-in whicls the Legislature has deliberately and repeatedly refused to act over the past six or more years." 114 Justice Mosk pointed out that the legislature knew age restrictions in lousing were common and had been upheld when challenged in court, ${ }^{115}$ yet liad "emplratically refused" to add age to the Unrulı Act's categories of prohibited discrimination eacli time the addition was proposed. ${ }^{116}$ The $O^{\prime} C o n n o r$ dissent thus reflects a more fundamental disagreement witli the majority's holding im Marina Point than does the dissent written in the latter case. In Marina Point, the same dissenting justices argued only that the complex's adult-oriented facilities rendered the landlord's age restriction reasonable, noting that had the trial court found the complex's premises to be designed for general use, they would have agreed that the limitation violated the Unruh Act. ${ }^{117}$ The $O^{\prime}$ Connor dissent manifests a broader rejection of the Marina Point holding because it correctly recognizes that the California Legislature did not intend the Unruh Act to prohibit age restrictions in lousmg at all.

111. 33 Cal. 3d 790, 662 P.2d 427, 191 Cal. Rptr. 320 (1983).

112. Id. at 796, 662 P.2d at 431,191 Cal. Rptr. at 324.

113. Id. at 794, 662 P.2d at 429-30, 191 Cal. Rptr. at 322-23.

114. Id. at 800, 662 P.2d at 434, 191 Cal. Rptr. at 327 (Mosk, J., dissenting).

115. Id. at 801, 662 P.2d at 434, 191 Cal. Rptr. at 327 (citing Ritchey v. Villa Neuva Condominium Ass'n, 81 Cal. App. 3d 688, 146 Cal. Rptr. 695 (1978), and Flowers v. John Burnham \& Co., 21 Cal. App. 3d 700, 98 Cal. Rptr. 644 (1971)). See supra text accoinpanying notes 39-40.

116. 33 Cal. 3d at 801, 662 P.2d at 434, 191 Cal. Rptr. at 327. Justice Mosk also questioned the distinction advanced by the Marina Point majority between age restrictions which limit occupancy to elderly persons and those which merely disallow occupancy by children, stating: "Age preference is age preference, regardless of the precise chronological point at which it is placed." Id. at $800,662 \mathrm{P} .2 \mathrm{~d}$ at $434,191 \mathrm{Cal}$. Rptr. at 327 . The dissenting justices also disagreed with the majority's holding that the nonprofit owners association was a business establishment under the Unruh Act. Id. at 801-03, 662 P.2d at 434-36, 191 Cal. Rptr. at 327-29.

117. $30 \mathrm{Cal} .3 \mathrm{~d}$ at $748,640 \mathrm{P} .2 \mathrm{~d}$ at 132, $180 \mathrm{Cal}$. Rptr. at 513 (Richardson, J., dissenting). 